\title{
Multi-Objective Optimization of LQR Control Quarter Car Suspension System using Genetic Algorithm
}

\author{
M. P. Nagarkar \\ SCSM College of Engineering \\ Ahmednagar (MS) - 414005 \\ AV College of Engineering, Sangamner \\ India \\ G. J. Vikhe Patil \\ AV College of Engineering,Sangamner, \\ Ahmednagar (MS),
}

In this paper, genetic algorithm (GA) based multi-objective optimization technique is presented to search optimum weighting matrix parameters of linear quadratic regulator (LQR). Macpherson strut suspension system is implemented for study. GA is implemented to minimize vibration dose values (VDV), RMS sprung mass acceleration, sprung mass displacement and suspension working space. Constraints are put on RMS sprung mass acceleration, maximum sprung mass acceleration, tyre deflection, unsprung mass displacement and RMS control force. Passive suspension system and LQR control active suspension system are simulated in time domain. Results are compared using class $E$ road and vehicle speed 80 kmph. For step response, GA based LQR control system is having minimum oscillations with good ride comfort. VDV is reduced by $16.54 \%$, $40.79 \%$ and $67.34 \%$ for Case I, II and III respectively. Same trend is observed for RMS sprung mass acceleration. Pareto-front gives more flexibility to choose optimum solution as per designer's need.

Keywords: Genetic Algorithm, Multi-objective optimization, Macpherson strut, Quarter car, $L Q R$

\section{INTRODUCTION}

Performance requirements for a suspension system are to adequately support the vehicle weight, to provide effective ride quality by isolating the chassis against excitations due to road roughness. Suspension system maintains the wheels in the appropriate position so as to have a better handling and keeps tire in contact with the ground. The passive suspension systems are trade-off between ride comfort and performance. A nice ride usually wallows through the corners whereas a car with high performance suspension will hang on tight through the corners but makes the passengers feel every dip and bump in the road.

The intent of the active suspension system is to replace the classical passive elements by a controlled system which can supply force to the system. Active suspension system dynamically responds to the changing road surface due to its ability to supply energy which is used to achieve the relative motion between the body and wheel, thus improving various performance criterions such as ride comfort, body displacement, suspension space requirements and tyre forces etc [1, 42]. Researchers had used various control strategies such as robust control, nonlinear control, nonlinear backstepping control, PID control, PI sliding mode control, Fuzzy logic control etc for active control. One of the main objectives was to minimize body acceleration to improve ride comfort.

In this paper, LQR control of quarter car suspension

Received: May 2015, Accepted: January 2016

Correspondence to: M. P. Nagarkar

SCSM College of Engineering,

Ahmednagar (MS)-414005. India.

E-mail: maheshnagarkar@rediffmail.com

doi:10.5937/fmet1602187N

(C) Faculty of Mechanical Engineering, Belgrade. All rights reserved system is presented. LQR control is an optimal control method with quadratic performance indexes. LQR is simple and can achieve closed loop optimal control with linear state feedback or output feedback. In designing $\mathrm{LQR}$ controller, the selection of weighting matrices is key issue which directly affects the control action.

Taghirad and Esmailzadeh [2] presented control of half car model travelling over random road using full state feedback controller. The weighting matrix $\mathrm{W}$ of LQR control is based on arbitrary choice. The proposed controller was effective in controlling the vibrations. Elmadany and Al-Majed [3] presented the LQR problem with full state feedback for suspension system. The weighting constants $\mathrm{q}_{1}, \mathrm{q}_{2}, \mathrm{q}_{3}$, and $\rho$, used to calculate matrices $\mathrm{Q}$ and $\mathrm{R}$ were selected based on the designer's preferences.

Zheng and Cheng. [4], Zhen et al. [5] and Darus and Enzai [6] presented LQR control scheme to control an actuator in an active suspension system. The values of weight matrices were selected for control application. It is observed that LQR controller performs better than passive system. Assadian [7] presented an optimal control study of actuator power and energy requirements. Linear lumped parameter 2 DoF quarter car model is used for control application with objective to minimize sprung mass response. The weight matrix, $\mathrm{Q}$, is chosen for $\mathrm{LQR}$ control application. Sam et al. [8] presented a model of a quarter car in state space form for control application. LQR controller is used for control application, where weight matrices were selected by the authors.

Esat et al. [9] implemented a 2 DoF linear quarter car model subjected to road disturbance for control application. This paper presented combined GA with convolution of integral and LQR controlled active suspension system. The weighting matrices parameters 
of LQR controller were chosen by conducting a series of tests, thus becomes trial and error method. The active controlled system suppresses sprung mass displacement as compared to passive system.

Oral et al. [10] presented an approach to LQR problem with an objective to translate the system's performance objectives into the cost function parameters. The selection of the elements of the performance index matrices, Q and R, was not carried out by trial and error but calculated for time domain design, which specifies steady and transient response of the system. The ratio between the weighting parameters was obtained using the mathematical relations. But, for minimum oscillations, the weighting parameters need to be adjusted.

Prabhakar et al. [11] presented a multi-objective control of semi-active suspension system with Magnetorheological (MR) damper. A quarter car is modelled for control application traversing over a stationary random road. The performance parameters of the semiactive system are obtained by comparing active suspension system based on LQR control. While modelling LQR controller, the weighting parameters, $\rho_{1}, \rho_{2}, \rho_{3}$ and $\rho_{4}$, were chosen arbitrarily as per designer's relative importance. It was observed that the performance of semi-active suspension system was very close to that of the active suspension system.

Active control of linear quarter car model by hydraulic actuator is implemented by Nekoui and Hadavi [12]. LQR controller is used for nonlinear hydraulic actuator control action. Hasbullah and Faris [13] presented a state space model of half car suspension system. LQR controller and fuzzy logic controller are implemented for control applications. Ismail et al. [14] presented the nonlinear feedback control of linear quarter car suspension system along with the LQR controller. Either LQR weight matrices were arbitrarily chosen by the authors for ride control application [2, 5, 6, 12, 14] or the weight matrices parameters of a LQR controller are adjusted by trial and error till desired performance is achieved $[9,10,13]$.

This paper presents the LQR control of a $2 \mathrm{DoF}$ Macpherson strut (Section 2) quarter car active suspension system. The multi objective LQR control is implemented in order to minimize VDV, RMS sprung mass acceleration, suspension working space and sprung mass displacement. During optimization, constraints are on RMS sprung mass acceleration, and maximum values of sprung mass acceleration, suspension space requirement, tyre deflection, unsprung mass displacement and control force. Due to multi-objective nature of LQR control action and objec-tive are conflicting; the key issue is to select the weight matrices of LQR controller so as to fulfil these require-ments. Arbitrarily choosing the weight matrices (trial and error method) is cumbersome and time consuming. Hence GA based search technique is implemented to search the optimum weight matrices parameters. Macpherson strut suspension system is simulated in Matlab/Simulink® environment. The output is fed to the optimization algorithm to determine objectives and checking the constraints. This optimization process is iteratively repeated till optimization stopping criterion is reached. In this paper, the number of generations is used as stopping criterion.

\section{MACPHERSON STRUT QUARTER CAR MODEL}

A suspension system of commercial vehicle consists of a coil springs and dampers. Various mathematical models had presented by researchers such and 2 DoF quarter car model, 4 DoF half car model and full car model. A 2 DoF and 4 DoF linear car model travelling on white noise Gaussian road surface [15]. A study about semi-active, nonlinear and robust control related to $1 \mathrm{D}$, half car and full car models was presented by Horvat [16]. A 2 DoF linear quarter car suspension system is modelled by various researchers $[4,6,7,8,9$, $11,12,14]$. The suspension system is modelled as lumped masses and linear springs and dampers.

In this paper, Macpherson strut quarter car suspension system is implemented. The Macpherson strut suspension was created by Earl Macpherson in 1949 for the Ford Company. This type of suspension is widely used in vehicles as it is compact in size and lightweight.

A model of the Macpherson strut suspension with spindle properties developed by Hong et al. [17] is implemented for ride control applications. The schematic of a Macpherson strut suspension is shown in Figure 1.

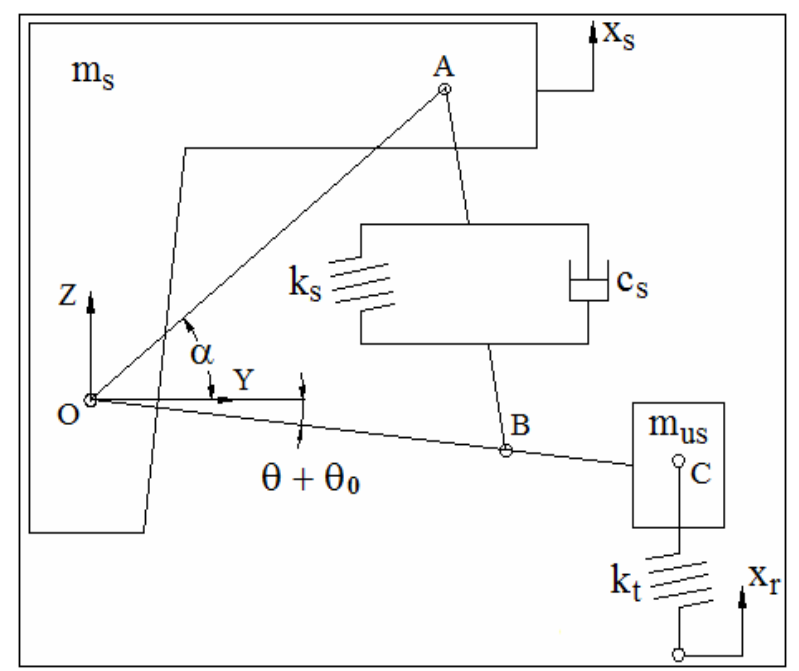

Figure 1. Macpherson strut quarter car model [17]

It consists of a quarter car body having sprung mass, a coil spring, damper, axle, tie rod and control arm. For equation of Motion for Macpherson Strut Model [17], refer APPENDIX 1.

For linearization the state variables are $\left[\mathrm{x}_{1}, \mathrm{x}_{2}, \mathrm{x}_{3}\right.$, $\left.\mathrm{x}_{4}\right]^{\mathrm{T}}=\left[\mathrm{xs}, \dot{\mathrm{x}} \mathrm{s}, \theta, \theta^{\prime}\right]^{\mathrm{T}}$ and output as $\ddot{\mathrm{x}}$. Linearization of equation (1) is carried out at an equilibrium point $(0,0$, $\theta \mathrm{o}, 0)[17]$.

The state space equation is (for details refer [17]):

$$
\dot{\mathrm{x}}(\mathrm{t})=\mathrm{Ax}(\mathrm{t})+\mathrm{B}_{1} \mathrm{f}_{\mathrm{LQR}}(\mathrm{t})+\mathrm{B}_{2} \mathrm{x}_{\mathrm{r}}(\mathrm{t})
$$

and

$$
y(t)=C x(t)+D_{1} f_{L Q R}(t)+D_{2} x_{r}(t)
$$

Here

$$
A=\left[\begin{array}{cccc}
0 & 1 & 0 & 1 \\
a_{21} & 0 & a_{23} & a_{24} \\
0 & 0 & 0 & 1 \\
a_{41} & 0 & a_{43} & a_{44}
\end{array}\right],
$$




$$
\begin{aligned}
& \mathrm{B} 1=\left[\begin{array}{c}
0 \\
\frac{1_{\mathrm{B}} \cos \left(-\theta_{0}\right)}{\mathrm{m}_{\mathrm{s}} \mathrm{l}_{\mathrm{C}}+\mathrm{m}_{\mathrm{us}} \mathrm{l}_{\mathrm{C}} \sin ^{2}\left(-\theta_{0}\right)} \\
0 \\
\frac{\left(\mathrm{m}_{\mathrm{s}}+\mathrm{m}_{\mathrm{us}}\right) 1_{\mathrm{B}}}{\mathrm{m}_{\mathrm{s}} \mathrm{m}_{\mathrm{us}} 1_{\mathrm{C}}{ }^{2}+\mathrm{m}_{\mathrm{us}}{ }^{2} \mathrm{l}_{\mathrm{C}}{ }^{2} \sin ^{2}\left(-\theta_{0}\right)}
\end{array}\right], \\
& \mathrm{B} 2=\left[\begin{array}{c}
0 \\
\frac{\mathrm{k}_{\mathrm{t}} \mathrm{l}_{\mathrm{C}} \sin ^{2}\left(-\theta_{0}\right)}{\mathrm{m}_{\mathrm{s}} \mathrm{l}_{\mathrm{C}}+\mathrm{m}_{\mathrm{us}} 1_{\mathrm{C}} \sin ^{2}\left(-\theta_{0}\right)} \\
0 \\
\frac{\mathrm{m}_{\mathrm{s}} \mathrm{k}_{\mathrm{t}} \mathrm{l}_{\mathrm{C}} \cos \left(-\theta_{0}\right)}{\mathrm{m}_{\mathrm{s}} \mathrm{m}_{\mathrm{us}} \mathrm{l}_{\mathrm{C}}{ }^{2}+\mathrm{m}_{\mathrm{us}}{ }^{2} \mathrm{l}_{\mathrm{C}}{ }^{2} \sin ^{2}\left(-\theta_{0}\right)}
\end{array}\right], \\
& C=\left[\begin{array}{cccc}
a_{21} & 0 & a_{23} & a_{24} \\
0 & 0 & 1 & 0
\end{array}\right] \\
& \mathrm{D} 1=\left[\begin{array}{c}
\frac{1_{\mathrm{B}} \cos \left(-\theta_{0}\right)}{\mathrm{m}_{\mathrm{s}} \mathrm{l}_{\mathrm{C}}+\mathrm{m}_{\mathrm{us}} \mathrm{l}_{\mathrm{C}} \sin ^{2}\left(-\theta_{0}\right)} \\
0
\end{array}\right] \text {, } \\
& \mathrm{D} 2=\left[\begin{array}{c}
\mathrm{k}_{\mathrm{t}} \mathrm{l}_{\mathrm{C}} \sin ^{2}\left(-\theta_{0}\right) \\
\mathrm{m}_{\mathrm{s}} 1_{\mathrm{C}}+\mathrm{m}_{\mathrm{us}} 1_{\mathrm{C}} \sin ^{2}\left(-\theta_{0}\right) \\
0
\end{array}\right] \text {, } \\
& a_{21}=\frac{-k_{t} l_{C} \sin ^{2}\left(-\theta_{0}\right)}{m_{s} l_{C}+m_{\text {us }} l_{C} \sin ^{2}\left(-\theta_{0}\right)} \text {, } \\
& a_{23}=\frac{1}{\left(m_{s} l_{C}+m_{u s} l_{C} \sin ^{2}\left(-\theta_{0}\right)\right)^{2}} \text {. } \\
& \left\{\begin{array}{l}
\frac{1}{2} \mathrm{k}_{\mathrm{s}}\left(\mathrm{b}_{1}+\frac{\mathrm{d}_{1}}{\left(\mathrm{c}_{1}-\mathrm{d}_{1} \cos \left(\alpha^{\prime}\right)\right)^{1 / 2}}\right)\left(\cos \left(\alpha^{\prime}+\theta_{0}\right)\right. \\
-\frac{1}{2}\left(\mathrm{k}_{\mathrm{s}} \sin \alpha^{\prime} \cos \left(-\theta_{0}\right)\left(\frac{\mathrm{d}_{1}^{2} \sin \alpha^{\prime}}{2\left(\mathrm{c}_{1}-\mathrm{d}_{1} \cos \alpha^{\prime}\right)^{3 / 2}}\right)\right. \\
-\mathrm{k}_{\mathrm{t}} \mathrm{l}_{\mathrm{C}}^{2} \sin ^{2}\left(-\theta_{0}\right) \cos \left(-\theta_{0}\right)
\end{array}\right] . \\
& \text {. }\left[\mathrm{m}_{\mathrm{s}} \mathrm{l}_{\mathrm{C}}+\mathrm{m}_{\mathrm{us}} \mathrm{l}_{\mathrm{C}} \sin ^{2}\left(-\theta_{0}\right)\right]+ \\
& \left.+\mathrm{m}_{\mathrm{us}} \mathrm{k}_{\mathrm{s}} \mathrm{l}_{\mathrm{C}} \sin \alpha^{\prime} \sin \left(-\theta_{0}\right) \cos ^{2}\left(-\theta_{0}\right)\left(\mathrm{b}_{1}+\frac{\mathrm{d}_{1}}{\left(\mathrm{c}_{1}-\mathrm{d}_{1} \cos \alpha^{\prime}\right)^{1 / 2}}\right)\right\} \\
& a_{24}=\frac{1}{m_{s} l_{C}+m_{u s} l_{C} \sin ^{2}\left(-\theta_{0}\right)} \cdot \frac{c_{s} b_{1}^{2} \sin ^{2} \alpha^{\prime}}{4\left(a_{1}-b_{1} \cos \alpha^{\prime}\right)}, \\
& \mathrm{a}_{41}=\frac{-\mathrm{m}_{\mathrm{s}} \mathrm{k}_{\mathrm{t}} \mathrm{l}_{\mathrm{C}} \cos \left(-\theta_{0}\right)}{\mathrm{m}_{\mathrm{s}} \mathrm{m}_{\text {us }} 1_{\mathrm{c}}^{2}+\mathrm{m}_{\text {us }}^{2} 1_{\mathrm{c}}^{2} \sin ^{2}\left(-\theta_{0}\right)} \text {, } \\
& \mathrm{a}_{43}=\frac{-\mathrm{m}_{\mathrm{s}} \mathrm{k}_{\mathrm{t}} \mathrm{l}_{\mathrm{C}} \cos \left(-\theta_{0}\right)}{\left(\mathrm{m}_{\mathrm{s}} \mathrm{m}_{\mathrm{us}} \mathrm{l}_{\mathrm{C}}^{2}+\mathrm{m}_{\text {us }}^{2} 1_{\mathrm{C}}^{2} \sin ^{2}\left(-\theta_{0}\right)\right)^{2}} \text {. } \\
& \cdot\left\{\begin{array}{l}
\frac{1}{2}\left(\mathrm{~m}_{\mathrm{s}}+\mathrm{m}_{\mathrm{us}}\right) \mathrm{k}_{\mathrm{s}} \cos \alpha^{\prime}\left(\mathrm{b} 1+\frac{\mathrm{d}_{1}}{\left(\mathrm{c}_{1}-\mathrm{d}_{1} \cos \alpha^{\prime}\right)^{1 / 2}}\right) \\
-\frac{1}{2}\left(\mathrm{~m}_{\mathrm{s}}+\mathrm{m}_{\mathrm{us}}\right) \mathrm{k}_{\mathrm{s}} \sin \alpha^{\prime}\left(\frac{\mathrm{d}_{1}^{2} \sin \alpha^{\prime}}{2\left(\mathrm{c}_{1}-\mathrm{d}_{1} \cos \alpha^{\prime}\right)^{3 / 2}}\right) \\
+\mathrm{m}_{\mathrm{s}} \mathrm{k}_{\mathrm{t}} \mathrm{l}_{\mathrm{C}}^{2} \cos \left(-\theta_{0}\right)
\end{array}\right] . \\
& \cdot\left[\mathrm{m}_{\mathrm{s}} \mathrm{m}_{\mathrm{us}} \mathrm{1}_{\mathrm{c}}^{2}+\mathrm{m}_{\text {us }}^{2} 1_{\mathrm{c}}^{2} \sin ^{2}\left(-\theta_{0}\right)\right]+
\end{aligned}
$$

$$
\begin{aligned}
& \left.+\frac{1}{2}\left(\mathrm{~m}_{\mathrm{s}}+\mathrm{m}_{\mathrm{us}}\right) \mathrm{m}_{\mathrm{us}}^{2} \mathrm{k}_{\mathrm{s}} \mathrm{l}_{\mathrm{c}}^{2} \sin \alpha^{\prime} \sin \left(-\theta_{0}\right)\left(\mathrm{b} 1+\frac{\mathrm{d}_{1}}{\left(\mathrm{c}_{1}-\mathrm{d}_{1} \cos \alpha^{\prime}\right)^{1 / 2}}\right)\right\} \\
& \mathrm{a}_{44}=\frac{-1}{\mathrm{~m}_{\mathrm{s}} \mathrm{m}_{\mathrm{us}} \mathrm{l}_{\mathrm{c}}^{2}+\mathrm{m}_{\mathrm{us}}^{2} \mathrm{l}_{\mathrm{c}}^{2} \sin ^{2}\left(-\theta_{0}\right)} \cdot \frac{\left(\mathrm{m}_{\mathrm{s}}+\mathrm{m}_{\mathrm{us}}\right) \mathrm{c}_{\mathrm{s}} \mathrm{b}_{1}^{2} \sin ^{2} \alpha^{\prime}}{4\left(\mathrm{a}_{1}-\mathrm{b}_{1} \cos \alpha^{\prime}\right)}
\end{aligned}
$$

\section{LQR CONTROLLER}

The LQR problem is a regulator problem using a linear system with a quadratic cost function. The LQR is an optimal control method for the linear system.

Let us consider the linear time invariant (LTI) system described in equation (2). Consider a state variable feedback regulator:

$$
\mathrm{f}_{\mathrm{LQR}}=-\mathrm{K}_{\mathrm{LQR}} \mathrm{x}
$$

The design procedure consists of determining the control input $\mathrm{f}_{\mathrm{LQR}}$, which minimizes the performance index. The performance index $\mathrm{J}_{\mathrm{LQR}}$ represents the performance characteristic requirement as well as the controller input limitation [18, 19, 32, 33]. In LQR, the quadratic performance index is expressed as:

$$
\mathrm{J}_{\mathrm{LQR}}=\int_{0}^{\infty}\left(\mathrm{x}^{\mathrm{T}} \mathrm{Q} \mathrm{x}+\mathrm{u}^{\mathrm{T}} \mathrm{Ru}\right) \mathrm{dt}
$$

where the matrix $\mathrm{Q}$ and $\mathrm{R}$ are positive-definite (or positive-semi definite) Hermitian or real symmetric matrices and are known as weighting matrices.

The first term on the right-hand side of the equation (5) accounts for the error between the initial and final state and second term accounts for the expenditure of the energy of the control signal. The matrices Q and R determine the relative importance of the error and expenditure of the performance index $[18,19,20,34$, 35] (For detailed controller design refer [18, 19]).

Gain matrix $\mathrm{K}_{\mathrm{LQR}}$, which minimizes $\mathrm{J}_{\mathrm{LQR}}$ is-

$$
\mathrm{K}_{\mathrm{LQR}}=\mathrm{R}^{-1} \mathrm{~B}^{\mathrm{T}} \mathrm{P}
$$

Matrix $\mathrm{P}$ is evaluated being the solution of the Algebraic Riccati Equation -

$$
\mathrm{AP}+\mathrm{A}^{\mathrm{T}} \mathrm{P}-\mathrm{PBR}^{-1} \mathrm{~B}^{\mathrm{T}} \mathrm{P}+\mathrm{Q}=0
$$

\section{MULTI-OBJECTIVE GENETIC ALGORITHM}

Genetic algorithm is an optimization and global search technique invented by J. H. Holland [21, 22]. This technique uses the principle of genetics and natural selection. GA search technique based on random numbers GA is stochastic algorithm. These random numbers determines the search result [21-23].

Nature of objective functions is conflicting, so multi objective optimization using NGPM (A NSGA-II Program in Matlab) is carried out. NGPM is the implementation of NSGA-II (Non-dominated Sort Genetic Algorithm) in Matlab [24, 25]. Firstly, non-dominated sorting is done using NSGA-II by compairing each individual with remaining solutions of a population [26] and thus all non-dominated solutions and non-dominated fronts are identified and ranked. For rank 1 individuals, fitness value 1 is assigned. For rank 2 individuals, fitness value 2 is assigned and so on [26, 36-38]. 
A new parameter, Crowding Distance (CD), is introduced by NSGA-II [26, 39, 40]. CD is the measure of diversity on individuals in the non-dominated population. After completing the sorting, $\mathrm{CD}$ is assigned to each individual, frontwise. More the $\mathrm{CD}$, more is the diversity in population. Individuals in the boundary are always selected as they have assigned infinite $\mathrm{CD}$.

From the non-dominated front, parents are selected on the basis of tournament selection and comparing the CD. New off-springs are created using crossover operator and mutation operator.

New off-springs and current population (parents) are combined to generate new population. Selection is carried out for next generation individuals.

Above steps are repeated till some convergence criterion such as number of generations or fitness or $\mathrm{CPU}$ time is reached. A flow chart of GA procedure is shown in Figure 2.

\section{a. Problem Statement}

While designing a suspension system, performance parameters which are under considerations are ride comfort, suspension travel (or rattle space), dynamic tyre force and road holding. The ride comfort is characterised by the RMS sprung mass acceleration, suspension travel is characterised by the relative travel between sprung mass and unsprung mass and dynamic tyre force is related to tyre deflection.

A major portion of the vibration experienced by the occupants of an automobile enters the body through the seat [27]. Whole-body vibrations, which are generally characterised by vertical vibrations, mostly affect the human body. These vibrations are transmitted to the buttocks and back of the occupant along the vertebral axis via the base. The health risk goes on increasing as the exposure time to vibrations goes on increasing. Hence is it necessary to measure the whole body vibrations. As per ISO 2631-1 [28], VDV is one measure for the whole body vibrations. VDV is also called the fourth power vibration dose, which is more sensitive to peak values. Hence VDV is used as one of the objective function. VDV is the method of assessing the cumulative effect (dose) of the vibration.

Here VDV, RMS sprung mass acceleration and maximum sprung mass displacement along with maximum suspension travel are considered as objective functions.

As per ISO 2631-1 [28], if weighted RMS sprung mass acceleration is below $0.315 \mathrm{~m} / \mathrm{s}^{2}$, passengers feels highly comfortable. According to Baumal et al. [29], at least $0.127 \mathrm{~m}$ (5 inch) of suspension travel is required and maximum sprung mass acceleration should not increase $4.5 \mathrm{~m} / \mathrm{s}^{2}$ so as to avoid hitting the suspension stops. Dynamic tyre force is characterised by tyre deflection. As tyre deflection increases the dynamic tyre force also increases. To minimise dynamic tyre forces, maximum tyre deflection should not increase $0.058 \mathrm{~m}$. Also for road holding upper limit of unpsrung mass displacement is $0.07 \mathrm{~m}$.

RMS sprung mass acceleration, maximum sprung mass acceleration, suspension travel, maximum tyre deflection, unsprung mass displacement and RMS controller force are the constraints for optimization.

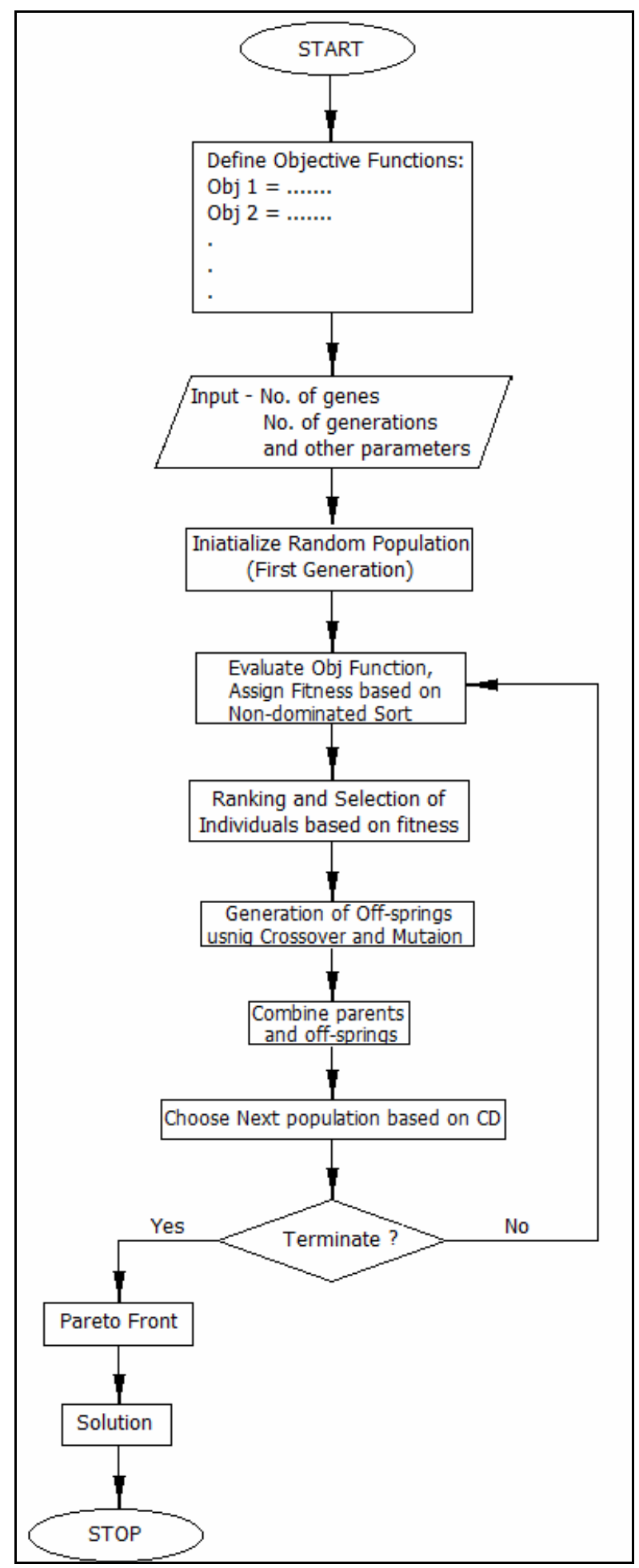

Figure 2. Flow Chart - Genetic Algorithm

GA based optimization technique is implemented to search $L Q R$ weighting matrices ( $Q$ and $R$ matrices). The formulation of optimization problem is:

Objective Function I $\quad \mathrm{f}_{\mathrm{obj} 1}=$ Minimize (VDV)

Objective Function II $: \mathrm{f}_{\mathrm{obj} 2}=$ Minimize $\left(\mathrm{a}_{\mathrm{RMS}}\right)$

Objective Function III: $\mathrm{f}_{\mathrm{obj} 3}=\operatorname{Minimize}\left(\max \left(\mathrm{x}_{\mathrm{s}}-\mathrm{x}_{\mathrm{us}}\right)\right)$

Objective Function IV: $\mathrm{f}_{\mathrm{obj} 4}=\operatorname{Minimize}\left(\max \left(\mathrm{x}_{\mathrm{s}}\right)\right)$

Subject to constraints:

$$
\begin{aligned}
& \operatorname{RMS}\left(\ddot{x}_{s}\right) \leq 0.315 \mathrm{~m} / \mathrm{s}^{2}, \operatorname{Max} .\left(x_{u}-x_{u s}\right) \leq 0.127 \mathrm{~m}, \\
& \operatorname{Max}\left(\ddot{x}_{s}\right) \leq 4.5 \mathrm{~m} / \mathrm{s}^{2}, \quad \operatorname{Max} .\left(x_{u s}-x_{r}\right) \leq 0.058 \mathrm{~m},
\end{aligned}
$$




$$
x_{u s} \leq 0.07 m,
$$

$R M S f_{L Q R} \leq 500 N$ GA

Parameters:

Population: 100,

Generations: 100 ,

Selection: Rank,

Mutation fraction: $0.5 \%$,

Crossover: Single point, Crossover fraction: $45 \%$

Search Space for $\mathrm{Q}$ and $\mathrm{R}$ Matrices:

$$
\begin{array}{ll}
10^{11} \leq \mathrm{Q}_{11} \leq 10^{10}, & 10^{7} \leq \mathrm{Q}_{22} \leq 10^{6}, \\
10 \leq \mathrm{Q}_{44} \leq 0.01, & 0.1 \leq \mathrm{R}_{1} \leq 0.001
\end{array}
$$

\section{RESULTS AND DISCUSSIONS:}

The LQR controller and GA based LQR controllers are simulated in Matlab® environment.

Quarter car parameters:

$$
\begin{array}{ll}
\mathrm{m}_{\mathrm{s}}=453 \mathrm{~kg} & \mathrm{~m}_{\mathrm{us}}=71 \mathrm{~kg} \\
\mathrm{k}_{\mathrm{s}}=17658 \mathrm{~N} / \mathrm{m} & \mathrm{c}_{\mathrm{s}}=1950 \mathrm{~N} \cdot \mathrm{sec} / \mathrm{m} \\
\mathrm{k}_{\mathrm{t}}=183887 \mathrm{~N} / \mathrm{m} & \\
\mathrm{l}_{\mathrm{A}}=0.66 \mathrm{~m}, \mathrm{l}_{\mathrm{B}}=0.34 \mathrm{~m}, \mathrm{l}_{\mathrm{C}}=0.37 \mathrm{~m}, \alpha=74^{\circ}, \theta \mathrm{o}=-2^{\circ}
\end{array}
$$

Road surface is described using power spectral density (PSD) [30]. Road is modelled using white noise signal having power spectral density 1 is represented by

$$
\dot{\mathrm{x}}_{\mathrm{r}}(\mathrm{t})+2 \Pi v \mathrm{n}_{0} \mathrm{x}_{\mathrm{r}}(\mathrm{t})=\sqrt{\mathrm{S}_{\mathrm{q}}\left(\Omega_{0}\right) \mathrm{v}} \mathrm{w}(\mathrm{t})
$$

From Equation (8), input road condition is modelled as class E road with degree of road roughness $2048 \times 10^{-6}$ $\mathrm{m}^{2} /($ cycle/m) [31]. The Vehicle is travelling with velocity of $80 \mathrm{kmph}$. Figure 3 represents time domain simulation of road surface.

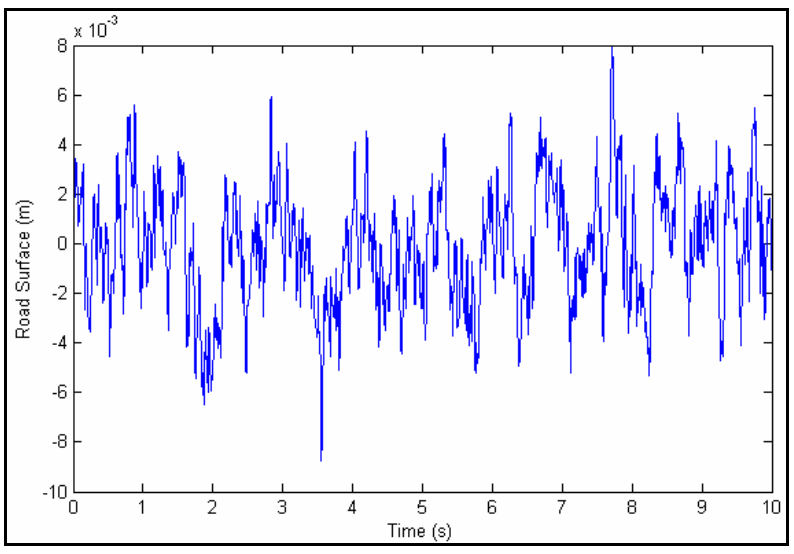

Figure 3. Road Surface (Class E, Velocity $80 \mathrm{kmph}$ )

Multi-objective optimization is carried out using the objective functions mentioned above. The pareto-front for the multi-objective optimization with four objective functions is shown in the Figure 4. Generally, the optimization is carried out with RMS sprung mass acceleration as objective function, to minimize the risk of health effects VDV is also included as an objective function. Also to minimize dynamic tyre forces and for good road holding, respective constraints have been introduced in the multi-objective optimization.

The GA optimized LQR controller and passive system are subjected to step response. Maximum overshoot and settling time are observed for the two systems as they are directly related to the ride comfort. A step of $0.05 \mathrm{~m}$ height is used for simulation. Figure 5 shows step response of sprung acceleration of passive (open loop) and LQR controlled system. Table 1 shows the maximum overshoot and settling time for passive and LQR system. LQR controlled system has minimum values of both parameters of step response as compared to the passive system.

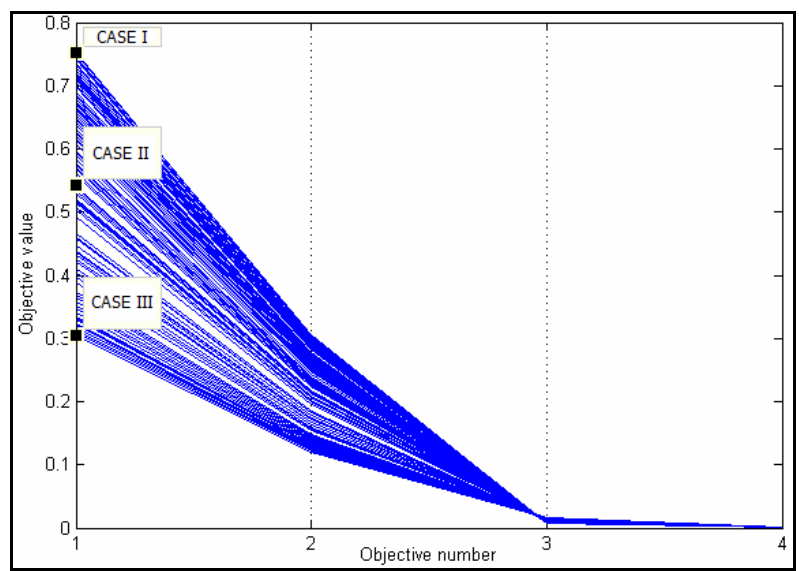

Figure 4. Pareto Front - Multi-objective Optimization (Population - 100, Generations - 100/100)

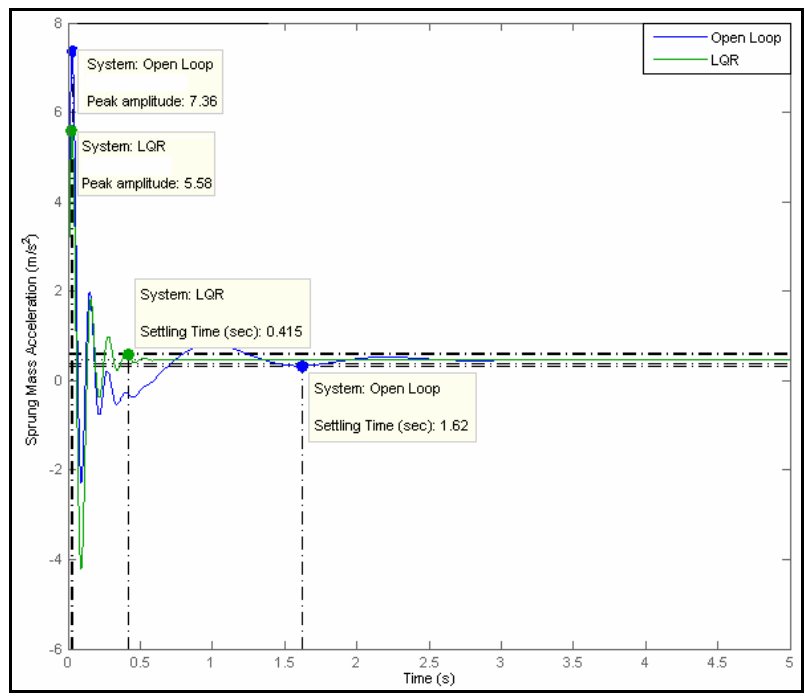

Figure 5. Step Response (Step Height 0.05 m)

Table 1. Step response

\begin{tabular}{|c|c|c|c|c|}
\hline \multirow{2}{*}{} & \multicolumn{2}{|c|}{$\begin{array}{c}\text { Maximum } \\
\text { Overshoot }\end{array}$} & \multicolumn{2}{c|}{$\begin{array}{c}\text { Settling Time } \\
(\mathrm{sec})\end{array}$} \\
\cline { 2 - 5 } & LQR & Passive & LQR & Passive \\
\hline $\begin{array}{c}\text { Sprung mass } \\
\text { acceleration (m/s2) }\end{array}$ & 5.58 & 7.36 & 0.415 & 1.62 \\
\hline
\end{tabular}

Three cases have been selected from the population of 100 for results and analysis. Case I is selected at the top of preto-front, Case II from the centre and Case III at the bottom. The LQR active control system is simulated using the respective weight matrices. The results are compared with the passive (open loop) suspension system.

Figure 6-8 shows the sprung mass acceleration, suspension space deflection and sprung mass displacement for passive suspension, LQR controlled Case I, II and III respectively. From Figure 7, it is observed that the suspension space deflection increases from Case I to III. Suspension space deflection is compromised for more ride comfort and VDV. For case III, maximum suspension space deflection is increased by 
$48 \%$ as compared to open loop. From Figure 8, sprung mass displacement is minimum for Case I, II and III as compared to open loop system. Figure 9 shows LQR controller force for LQR controlled Case I, II and III respectively. It is observed that as ride comfort increases, so the requirement of LQR control force also increases.

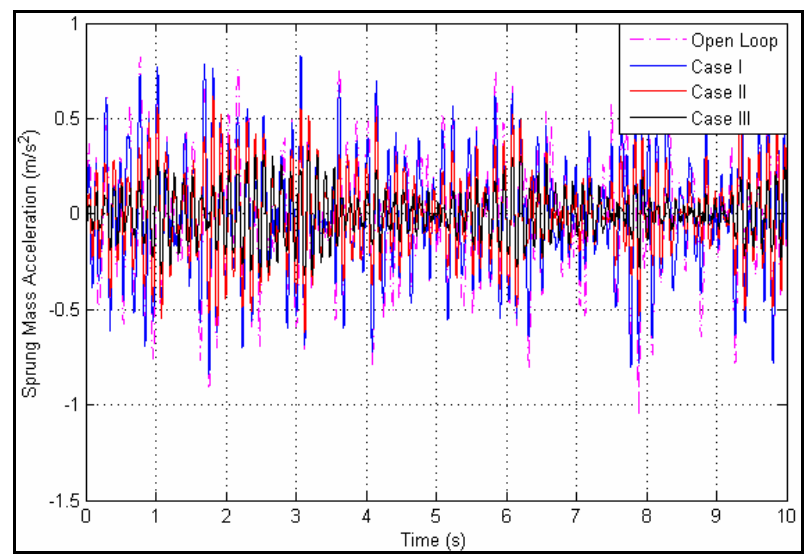

Figure 6: Sprung Mass Acceleration - Quarter Car Model.

Table 2 shows the comparative results of passive (open loop) system and LQR control active suspension system. From Table 2, it is observed that VDV is reduced by $16.54 \%$ as compared to passive system for case I. Also reduction of $40.79 \%$ and $67.34 \%$ is observed in VDV for case II and III respectively. RMS sprung mass acceleration is reduced by $17.74 \%, 42.05 \%$ and $67.67 \%$ for case I, II and III respectively. Decrease in sprung mass displacement is observed from Case I to Case III.

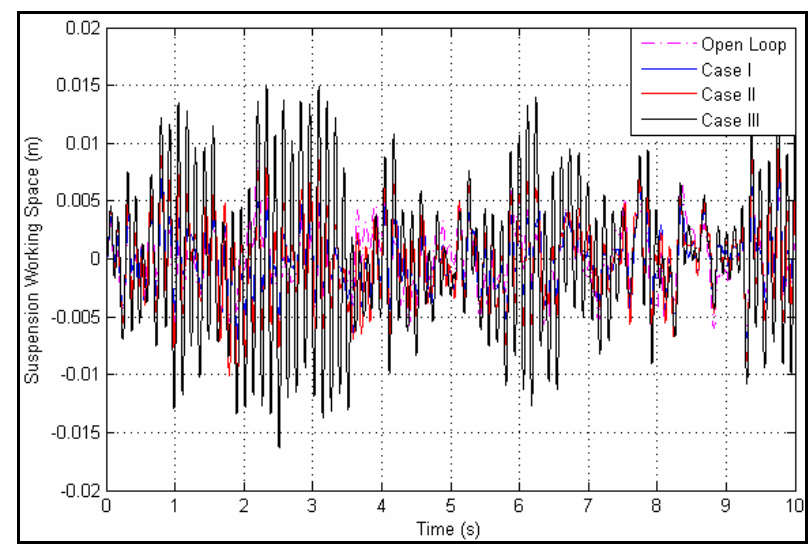

Figure 7: Suspension Deflection - Quarter Car Model.

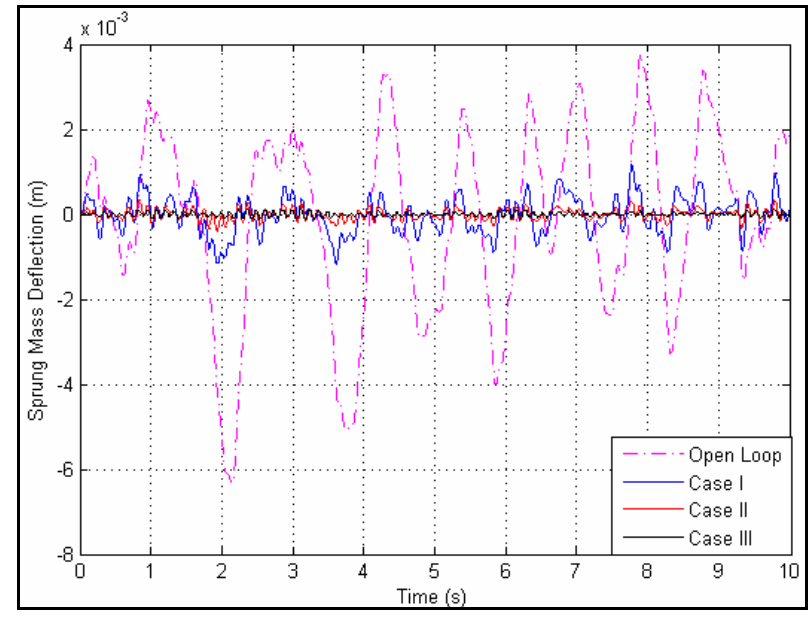

Figure 8: Sprung Mass Displacement - Quarter Car Model.

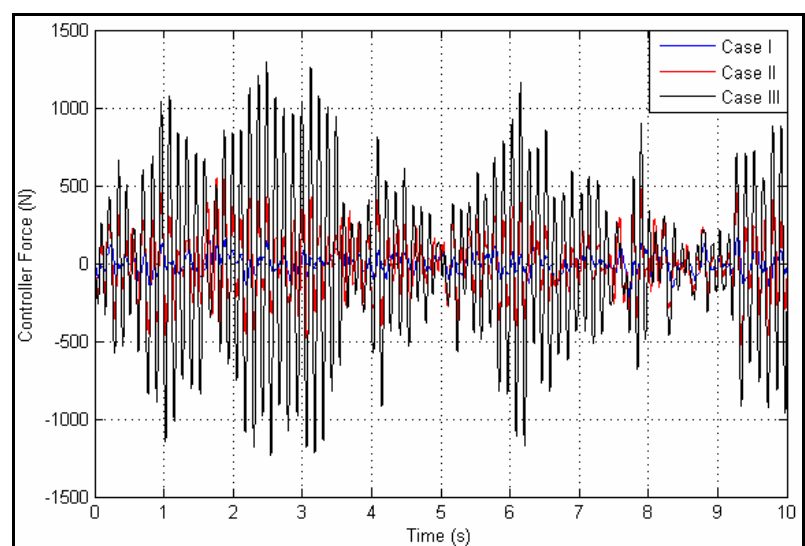

Figure 9: LQR Controller Force.

A trade-off is observed between VDV and maximum suspension space deflection. As VDV decreases maximum suspension space deflection increases. Same trend is observed between VDV and maximum tyre deflection and between VDV and unsprung mass displacement for Case I, II and III.

From Table 2, it observed that constraints on Suspension working space, RMS sprung mass acceleration, maximum sprung mass acceleration, tyre deflection and unsprung mass displacement are not violated. During optimization RMS controller force is constrained up to $500 \mathrm{~N}$. The constrained on RMS controller force is not violated during multi-objective optimization. Trade-off is observed between VDV and RMS sprung mass acceleration and RMS controller force.

From Table 2 it is observed that, for Case II VDV and RMS sprung mass acceleration is reduced by $39.09 \%$ and $41.95 \%$ respectively as compared to Case I. Whereas, Case II has $155.19 \%$ less RMS controller force requirement as compared to Case III. Hence designer may choose Case II solution. Moreover pareto front, shown in Figure 4, gives more flexibility to designers to choose optimum solution.

Previous discussions based on the time domain analysis of LQR controlled Macpherson strut quarter car suspension system. The vehicle is travelling over a class E random road at constant speed of $80 \mathrm{kmph}$. To demonstrate the frequency domain analysis of the suspension system, Bode plots are shown in the Figure 10,11 and 12 .

The optimization of LQR control suspension is for carried for one vehicle speed. Figure 10 shows frequency response plot of the quarter car model from inputs $\mathrm{x}_{\mathrm{r}}$ to output $\ddot{x}_{s}$. Figure shows open loop response and closed loop frequency response for Case I, II and III. It is observed that closed loop response provides better ride as compared to open loop response over frequency range. Similar results can be observed from the frequency response plot of quarter car model from inputs $x_{r}$ to output $\mathrm{X}_{\mathrm{s}}$. Here, for case I, II and III peak occurs beyond the body natural frequency with lower magnitude values as compared to open loop response. Refer Figure 11.

Figure 12 shows frequency response plot of the quarter car model from inputs $\mathrm{x}_{\mathrm{r}}$ to output $\left(\mathrm{x}_{\mathrm{s}}-\mathrm{x}_{\mathrm{us}}\right)$. It is observed that suspension space requirements by closed loop response are better as compared to open loop frequency response. Natural frequency of rattle space is $21.2448 \mathrm{rad} / \mathrm{sec}$. 
Table 2. Response of passive LQR controlled active suspension system.

\begin{tabular}{|l|c|c|c|c|c|c|c|c|}
\hline Type & VDV & $\begin{array}{c}\text { RMS }\left(\ddot{\mathrm{X}}_{\mathrm{s}}\right) \\
\left(\mathrm{m} / \mathrm{s}^{2}\right)\end{array}$ & $\begin{array}{c}\text { Max Sprung } \\
\text { Mass } \\
\text { Displacement } \\
(\mathrm{m})\end{array}$ & $\begin{array}{c}\text { Max. } \\
\text { Suspension } \\
\text { Space } \\
\text { Deflection } \\
(\mathrm{m})\end{array}$ & $\begin{array}{c}\text { Max }\left(\ddot{\mathrm{x}}_{\mathrm{s}}\right) \\
\left(\mathrm{m} / \mathrm{s}^{2}\right)\end{array}$ & $\begin{array}{c}\text { Max. Tyre } \\
\text { Deflection } \\
(\mathrm{m})\end{array}$ & $\begin{array}{c}\text { Max } \\
\text { Unsprung } \\
\text { Mass } \\
\text { Displacement } \\
(\mathrm{m})\end{array}$ & $\begin{array}{c}\text { RMS } \\
\mathrm{f}_{\mathrm{LQR}} \\
(\mathrm{N})\end{array}$ \\
\hline Passive & 0.9132 & 0.3731 & 0.006348 & 0.008443 & 1.0606 & 0.0159 & 0.0193 & - \\
\hline Case I & 0.7521 & 0.3069 & 0.001171 & 0.007532 & 0.9833 & 0.0131 & 0.0068 & 63.0199 \\
\hline Case II & 0.5407 & 0.2162 & 0.000392 & 0.011097 & 0.6196 & 0.0156 & 0.0109 & 189.296 \\
\hline $\begin{array}{l}\text { Case } \\
\text { III }\end{array}$ & 0.3041 & 0.1206 & 0.000133 & 0.016321 & 0.3278 & 0.0192 & 0.0163 & 483.075 \\
\hline
\end{tabular}

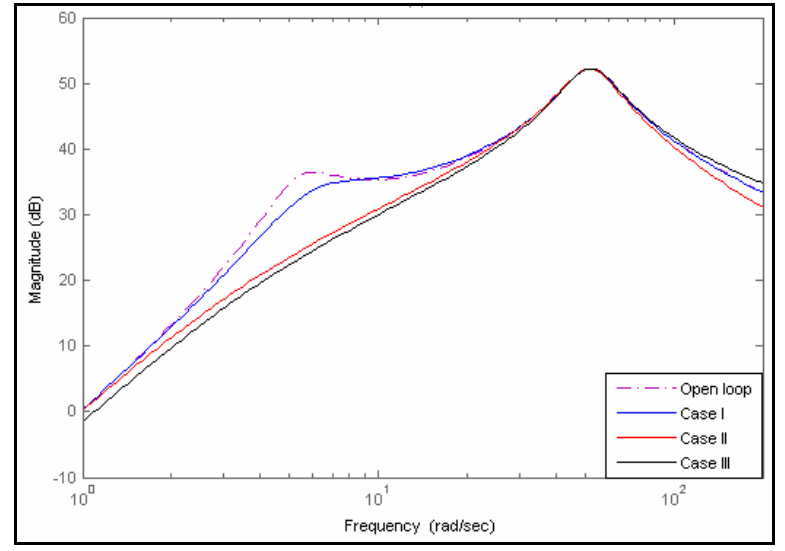

Figure 10: Frequency Response of Sprung Mass Acceleration.

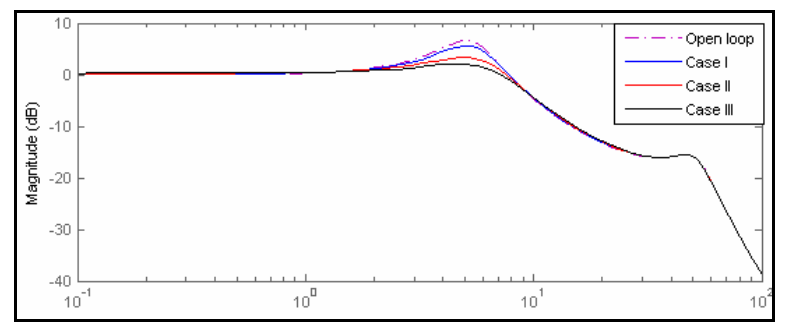

Figure 11: Frequency Response of Sprung Mass Displacement.

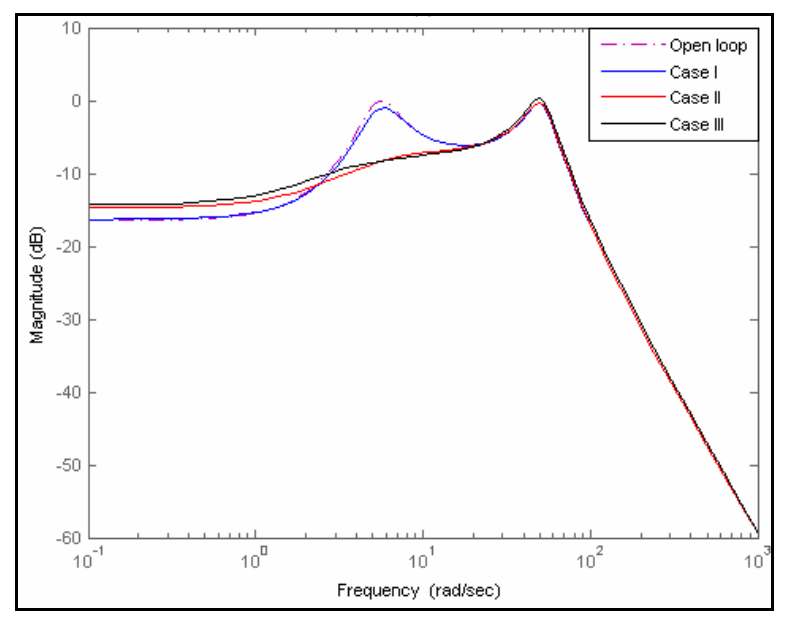

Figure 12: Frequency Response of Suspension Space.

Here sprung mass acceleration and suspension space are reduced in Case I, II and III as compared to open loop response below rattle space frequency.

Optimal control of linear 2 DoF vehicle suspension based on simulated annealing (SA) optimization algorithm was presented by Meng et al. The LQR control weight matrices were searched using vertical acceleration of sprung mass, suspension space displacement and tyre displacement as objective functions. Multi-objective optimization problem was converted into uni-objective optimization problem using normalization. During simulation the vehicle was travelling over class B road at $20 \mathrm{kmph}$ speed. Sprung mass acceleration was observed $0.3326 \mathrm{~m} / \mathrm{s} 2$ and suspension space travel was observed $0.3548 \mathrm{~m}$ using SA optimized LQR control [41].

Whereas current GA based optimization technique incorporates multi-objective optimization. Current paper discusses optimization using Macpherson strut quarter car model travelling over class E road at $80 \mathrm{kmph}$ speed. For validation, the GA optimized LQR control is compared with un-optimized LQR control. In multi-objective optimization, for Case I, II and III, RMS sprung mass acceleration is observed $0.3069,0.2162$ and $0.1206 \mathrm{~m} / \mathrm{s} 2$ respectively which is less than $0.3326 \mathrm{~m} / \mathrm{s} 2$ obtained by SA. Also in present study of optimization, VDV is also introduced as one of the objective function as a measure of driver health. In GA, population of 100 genes is used; hence pareto front of 100 different solutions is obtained which gives designers more flexibility.

\section{CONCLUSION}

Multi-objective optimization of weighting matrices LQR controller using GA is presented in this paper. A Macpherson strut quarter car suspension model is used for control application.

- Instead of trial and error or adjusting the weighting matrix parameters of LQR controller, GA based optimization method is proposed to determine the parameters for several objectives.

- Multi-objective optimization with four objectives namely VDV, RMS sprung mass acceleration, maximum sprung mass displacement and maximum suspension space deflection is successfully implanted using multi-objective GA.

- In determining the weight matrices of LQR controller, along with ride comfort and stability of a vehicle passenger health criterion is included in the objective function.

- From step response, for LQR controlled system, sprung mass acceleration has $24.18 \%$ reduction in 
maximum overshoot. Also settling time is very less as compared to open loop system. Thus the LQR controlled system is having minimum oscillations with good ride comfort.

- VDV is reduced by $16.54 \%, 40.79 \%$ and $67.34 \%$ for Case I, II and III respectively as compared to passive suspension system. Same trend is observed for RMS sprung mass acceleration.

- From frequency domain analysis, body acceleration and suspension space requirements are reduced by LQR controlled closed loop response of Macpherson strut quarter car suspension system.

- In multi-objective optimization, pareto front provides greater flexibility to designers to choose the solution from the set of solutions as per the requirement.

\section{ACKNOWLEDGMENT}

First Author would like to thank the Management of A.J.M.V.P.S., Ahmednagar and Principal of SCSMCoE for kind help during research work. Also First Author would like to thank Dr. RV Rao, Professor SVNIT Surat, India for their constructive suggestions on multiobjective optimization.

\section{REFERENCES}

[1] Fuller, C.R., Elloit, S.J., Nelson P.A.: Active Control of Vibrations, Academic Press London, 1996.

[2] Taghirad H.D., Esmailzadeh, E.: Automobile passenger comfort assured through LQG/LQR active suspension, Vibration and Control, Vol. 4, No. 5, pp. 603-618, 1998.

[3] Elmadany, M.M., Al-Majed, M.I.: Quadratic Synthesis of Active Controls for a Quarter-Car Model, Journal of Vibration and Control, Vol. 7, pp. 1237-1252, 2001

[4] Zhen, L., Cheng, L.: Road Adaptive Active Suspension Control Design. in: Proceedings of IMACS Multiconference on Computational Engineering in Systems Applications 2006, Beijing, Chin, pp. 1347-1350.

[5] Zhen, L., Luo,C., Hu, D.: Active Suspension Control Design Using a Combination of LQR and Backstepping, in: Proceedings of the 25th Chinese Control Conference, 2006, China, pp. 123-125.

[6] Darus, R., Enzai, N.I.: Modeling and Control Active Suspension System for a Quarter Car Model, in: Proceedings of International Conference on Science and Social Research (CSSR 2010), Malaysia, pp. 1203-1206.

[7] Assadian, F.: A comparative study of optimal linear controllers for vibration suppression, Journal of the Franklin Institute, Vol. 339, pp. 347-360, 2002.

[8] Sam, Y.M., Osman, H.S.O., Ghani, M.R.A.: A Class of Proportional-Integral sliding Mode Control with Application to Active Suspension System, System and Control Letters, Vol. 51, 217-223, 2004.

[9] Esat, I.I., Saud, M., Engin, S.N.: A novel method to obtain real-time control force strategy using genetic algorithms for dynamic systems subjected to external arbitrary excitations, Journal of Sound and Vibration, Vol. 330, 27-48, 2011.

[10] Oral, Ö., Çetin, L., Uyar, E.: A Novel Method on Selection of Q And R Matrices in the Theory of Optimal Control, International Journal of Systems Control, Vol. 1, No. 2, pp. 84-92, 2010.

[11] Prabakar, R.S., Sujatha, C., Narayanan, S.: Response of a quarter car model with optimal magnetorheological damper parameters, Journal of Sound and Vibration, Vol. 332, 2191-2206, 2013.

[12] Nekoui, M.A., Hadavi, P.: Optimal Control of an Active Suspension System, in: Proceedings of 14th International Power Electronics and Motion Control Conference, 2010, EPE-PEMC, pp. T5-60 - T5-63.

[13] Hasbullah, F., Faris, W. F.: A comparative Analysis of LQR and Fuzzy Logic Controller for Active Suspension Using Half Car Model, in: Proceedings of 11th Int. Conf. Control, Automation, Robotics and Vision, 2010, Singapore, pp.2416-2420.

[14] Ismail, M.F., Peng, K., Hamzah, N., Sam, Y.M., Aripin, M., Hasan,M.H.C.: A Linear Model of Quarter Car Active Suspension System Using Composite Nonlinear Feedback Control, in: Proceedings of IEEE Student Conference on Research and Development, 2012, Paula Pinang, pp. 98-103.

[15] Hrovat, D.:Optimal suspension performance for 2D vehicle models, Journal of Sound and Vibration, Vol. 146, No. 1, pp. 93-110, 1991.

[16] Hrovat, D.: Survey of Advanced Suspension Developments and Related Optimal Control Applications, Automatica, Vol. 33, No. 10, pp. 1781-1817, 1997.

[17] Hong, K.S., Jeon, D.S., Yoo, W.S., Sunwoo, H., Shin, S.Y., Kim, C.M., Park, B.S.: A New Model and an Optimal Pole-Placement Control of the Macpherson Suspension System, SAE Technical Paper 1999-01-1331, 1-10, 1990.

[18] Anderson, B., Moore, J.: Optimal Control - Linear Quadratic Methods, Prentice Hall, NJ, 1990.

[19] Ogata, K.: Modern Control Engineering, Prentice Hall India, 2002.

[20] Nagarkar, M.P., Vikhe Patil, G.J.: Performance Analysis of Quarter Car Active Suspension System: LQR and $\mathrm{H} \infty$ Control Strategies, in: Proceedings of International Conference on Computing, Communication and Networking Technology ICCCNT'12, 2012, India, pp. 1-6.

[21] Holland, J. H.: Adaptation in Natural and Artificial Systems, University of Michigan Press, 1975.

[22] Holland, J.H.: Genetic Algorithms, Scientific American. Vol. 267, pp. 66-72, 1992.

[23] Goldberg, D.E.: Genetic Algorithms in Search, Optimization, and Machine Learning, AddisonWesley, Reading, MA, 1989.

[24] Song, L.: NGPM-A NSGA-II Program in Matlab User Manual, Version 4.1, pp. 1-20, 2011. 
[25] Song, L. NGPM_v14, Matlab Code. http://www.mathworks.com/matlabcentral/fileexch ange. Accessed 14 January 2014.

[26] Deb, K., Pratap, A., Agarwal, S., Meyarivan, T.: A Fast and Elitist Multiobjective Genetic Algorithm: NSGA-II, IEEE Transactions on Evolutionary Computation, Vol. 6, No. 2, pp. 182-197, 2002.

[27] Nawayseh, N..: The use of Seat Effective Amplitude Transmissibility (SEAT) Values to Predict Dynamic Seat comfort, Journal of Sound and Vibration, Vol. 260, pp. 867-888, 2003.

[28] ISO: 2631-1: Mechanical vibration and shock Evaluation of human exposure to whole-body vibration, 1997.

[29] Baumal, A.E., McPhee, J.J., Calamai, P.H.: Application of genetic algorithms to the design optimization of an active vehicle suspension system, Computer Methods in Applied Mechanics and Engineering, Vol. 163, pp. 87-94, 1998.

[30]Zhang, Y., Chen, W., Chen, L., Shangguan, W.: Non-stationary Random Vibration Analysis of Vehicle with Fractional Damping, in: Proceedings of 13th National Conference on Mechanisms and Machines (NaCoMM07), 2007, India, pp. 171-178.

[31]ISO, Reporting vehicle road surface irregularities, Technical Report, ISO, ISO/TC108/SC2/WG4 N57, 1982.

[32] Yoon, S., Lee, S., Lee, B., Kim, C., Lee, Y., and Sung, S.: Design and Flight Test of a Small TriRotor Unmanned Vehicle with a LQR Based Onboard Attitude Control System, International Journal of Innovative Computing, Information and Control, Vol. 9(6), pp.2347-2360, 2013.

[33] Wei, X., Li, J., Liu, X.: LQR control scheme for active vehicle suspension systems based on modal decomposition, in Proceedings of 25th Chinese Control and Decision Conference, 2013, China, pp. 3296 - 3301 .

[34] Jahromi, A.F., Zabihollah, A.: Linear Quadratic Regulator and Fuzzy controller application in fullcar model of suspension system with Magnetorheological shock absorber, in Proceeding of IEEE/ASME International Conference on Mechatronics and Embedded Systems and Applications (MESA), 2010, pp. 522 - 528.

[35] Selamat, H., Bilong, S.D.A.: Optimal controller design for a railway vehicle suspension system using Particle Swarm Optimization, in Proceedings of 9th Asian Control Conference, 2013, pp.1-5.

[36] Shang, R., Zhang, K., Jiao, L., Fang, W., Zhang, X., Tian, X. :A novel algorithm for many-objective dimension reductions: Pareto-PCA-NSGA-II, in Proceedings IEEE Congress on of Evolutionary Computation (CEC), 2014, pp.1974-1981.

[37] Wang, X., Zheng, Z. :Multi-objective optimization of the loading path for tube hydroforming process based on NSGA- II, in Proceedings of 2nd International Conference on Artificial Intelligence, Management Science and Electronic Commerce (AIMSEC), 2011, pp.1247-1251.
[38] Bandyopadhyay, S., Bhattacharya, R. :NSGA-II based multi-objective evolutionary algorithm for a multi-objective supply chain problem, in Proceedings of International Conference on Advances in Engineering, Science and Management (ICAESM), 2012, pp.126-130.

[39] Amirahmadi, A., et al: Multi-Objective optimum design of controller for PFC rectifier using NSGAII algorithm, in Proceedings of 1st Power Electronic \& Drive Systems \& Technologies Conference (PEDSTC), 2010 , pp.180-185.

[40] Martins, M., Santos, C., Costa, L., Frizera, A. :Gait feature selection in walker-assisted gait using NSGA-II and SVM hybrid algorithm, in Proceedings of 22nd European Signal Processing Conference (EUSIPCO), 2014, pp.1173-1177.

[41] Meng, J., Chen, Q., He, R.: Research on optimal control for the vehicle suspension based on simulated annealing algorithm, Journal of Applied Mathematics, pp. 1-5, 2014.

[42] Guida, D., Pappalardo, C.: A New Control Algorithm for Active Suspension Systems Featuring Hysteresis, FME Transactions, 41 pp. 285-290, 2013.

\section{NOMENCLATURE}

\begin{tabular}{|c|c|}
\hline A & System Matrix \\
\hline $\mathrm{B}_{1}$ & Control Input Matrix \\
\hline $\mathrm{B}_{2}$ & Disturbance Matrix \\
\hline $\mathrm{c}_{\mathrm{s}}$ & Suspension damping coefficient (Ns/m) \\
\hline$f_{L Q R}$ & LQR control force \\
\hline$f_{\max }$ & Maximum LQR control force $(\mathrm{N})$ \\
\hline$f_{\text {obj }}$ & Objective Function \\
\hline $\mathrm{J}_{\mathrm{LQR}}$ & Quadratic Performance Index \\
\hline $\mathrm{K}_{\mathrm{LQR}}$ & State Feedback gain matrix \\
\hline $1_{\mathrm{A}}$ & Distance OA (m) \\
\hline $1_{B}$ & Distance OB (m) \\
\hline $1_{\mathrm{C}}$ & Control arm length (m) \\
\hline $\mathrm{m}_{\mathrm{s}}$ & Sprung mass $(\mathrm{kg})$ \\
\hline $\mathrm{m}_{\mathrm{us}}$ & Unsprung mass $(\mathrm{kg})$ \\
\hline $\mathrm{N}$ & No. of samples \\
\hline $\mathrm{n}_{0}$ & Ref Spatial Frequency $=0.1($ cycle $/ \mathrm{m})$ \\
\hline $\mathrm{P}$ & Positive definite matrix \\
\hline $\mathrm{Q}, \mathrm{R}$ & LQR weighting matrices \\
\hline $\operatorname{Sq}\left(\Omega_{0}\right)$ & Degree of road roughness $(\mathrm{m} 2 /($ cycle $/ \mathrm{m})$ \\
\hline $\mathrm{u}$ & Control vector \\
\hline VDV & Vibration Dose Value (m/s1.75) \\
\hline $\mathrm{V}$ & Vehicle speed $(\mathrm{m} / \mathrm{s})$ \\
\hline $\mathrm{w}(\mathrm{t})$ & White noise signal \\
\hline $\mathrm{x}$ & State Vector \\
\hline $\mathrm{X}_{\mathrm{r}}$ & Road profile (m) \\
\hline $\mathrm{x}_{\mathrm{s}}$ & Sprung mass displacement $(\mathrm{m})$ \\
\hline$\dot{\mathrm{x}}_{\mathrm{s}}$ & Sprung mass velocity $(\mathrm{m} / \mathrm{s})$ \\
\hline$\ddot{\mathrm{x}}_{\mathrm{s}}$ & Sprung mass acceleration $\left(\mathrm{m} / \mathrm{s}^{2}\right)$ \\
\hline $\operatorname{Max}\left(\ddot{x}_{\mathrm{s}}\right)$ & Max Sprung mass acceleration $\left(\mathrm{m} / \mathrm{s}^{2}\right)$ \\
\hline $\operatorname{RMS}\left(\ddot{\mathrm{x}}_{\mathrm{s}}\right)$ & RMS Sprung mass acceleration $\left(\mathrm{m} / \mathrm{s}^{2}\right)$ \\
\hline $\mathrm{X}_{\mathrm{us}}$ & Unsprung mass displacement (m) \\
\hline
\end{tabular}

\section{Greek symbols}

Angle made by link OA with horizontal $\left({ }^{\circ}\right)$ 
$\theta \quad$ Rotation angle of control arm $\left({ }^{\circ}\right)$

$\theta_{\mathrm{o}} \quad$ Initial angle of rotation of control arm $\left(^{\circ}\right)$

\section{ВИШЕЦИЉНА ОПТИМИЗАЦИЈА УПРАВЉАЊА LQR СИСТЕМА ВЕШАЫА АУТОМОБИЛА КОРИШЋЕЊЕМ ГЕНЕТСКОГ АЛГОРИТМА}

\section{М.П. Нагаркар, Г.Ј.В. Патил}

У раду је приказана техника вишециљне оптимизације засноване на генетском алгоритму, која се користи за изналажење оптималних параметара тежинске матрице код линеарног квадратног регулатора. У истраживањима је примењено Макферсоново вешање. Генетски алгоритам се користи за минимизирање вредности дозе вибрација, квадратног корена просечног убрзања овешане масе, помераја овешане масе и радног простора овешане масе. Ограничења су узета за квадратни корен просечног убрзања овешане масе, максимално убрзање овешане масе, крутост пнеуматика, померај неовешане масе и квадратни корен просека силе управљања. Извршена је симулација пасивног система вешања и управљања активним системом вешања помоћу линеарног квадратног регулатора у временском домену. Извршено је поређење резултата добијених за друм класе Е и брзине возила од 80 км/час. Код степенасте реакције систем управљања помоћу линеарног квадратног регулатора заснованог на генетском алгоритму има минимум осцилација за комфорну вожњу. Вредности дозе вибрација су редуковане за $16,54 \%, 40,79 \%$ и $67,34 \%$ за случајеве 1 односно 2 односно 3. Иста тенденција постоји и код квадратног корена просечног убрзања овешане масе. Парето фронт обезбеђује већу флексибилност у избору оптималног решења за потребе пројектовања.

\section{APPENDIX 1: EQUATIONS}

$$
\left.\begin{array}{l}
\left(\mathrm{m}_{\mathrm{s}}+\mathrm{m}_{\mathrm{us}}\right) \ddot{\mathrm{x}}_{\mathrm{s}}+\mathrm{m}_{\mathrm{us}} \mathrm{l}_{\mathrm{C}} \cos \left(\theta-\theta_{0}\right) \ddot{\theta}-\mathrm{m}_{\mathrm{us}} \mathrm{l}_{\mathrm{C}} \sin \left(\theta-\theta_{0}\right) \dot{\theta}^{2}+\mathrm{k}_{\mathrm{t}}\left(\mathrm{x}_{\mathrm{s}}+\mathrm{l}_{\mathrm{C}}\left(\sin \left(\theta-\theta_{0}\right)-\sin \left(-\theta_{0}\right)-\mathrm{x}_{\mathrm{r}}\right)\right)=0 \\
\mathrm{~m}_{\mathrm{us}} \mathrm{l}_{\mathrm{C}}{ }^{2} \ddot{\theta}+\mathrm{m}_{\mathrm{us}} \mathrm{l}_{\mathrm{C}} \cos \left(\theta-\theta_{0}\right) \ddot{\mathrm{x}}_{\mathrm{s}}+\frac{\mathrm{c}_{\mathrm{p}} \mathrm{b}_{1}{ }^{2} \sin \left(\alpha^{\prime}-\theta_{0}\right) \dot{\theta}}{4\left(\mathrm{a}_{1}-\mathrm{b}_{1}\left(\cos \left(\alpha^{\prime}-\theta\right)\right)\right.}+\mathrm{k}_{\mathrm{t}} \mathrm{l}_{\mathrm{C}} \cos \left(-\theta_{0}\right)\left(\mathrm{x}_{\mathrm{s}}+\mathrm{l}_{\mathrm{C}} \sin \left(\theta-\theta_{0}\right)-\sin \left(-\theta_{0}\right)\right) \\
-\mathrm{x}_{\mathrm{r}}-\frac{1}{2} \mathrm{k}_{\mathrm{s}} \sin \left(\alpha^{\prime}-\theta\right)\left[\mathrm{b}_{1}+\frac{\mathrm{d}_{1}}{\left(\mathrm{c}_{1}-\mathrm{d}_{1} \cos \left(\alpha^{\prime}-\theta\right)^{1 / 2}\right)}\right]=-\mathrm{l}_{\mathrm{B}} \mathrm{F}_{\mathrm{LQR}}
\end{array}\right\}
$$

where,

$\alpha^{\prime}=\alpha+\theta_{0}, a_{1}=1_{A}^{2}+l_{B}^{2}, b_{1}=2 l_{A} l_{B}, c_{1}=a_{1}^{2}-a_{1} b_{1} \cos \left(\alpha+\theta_{0}\right), d_{1}=a_{1} b_{1}-b_{1}^{2} \cos \left(\alpha+\theta_{0}\right)$ 